\title{
鉄鋼の水溶液腐食試験に関する二，三の試久*
}

\author{
日 根交 男** 保 田昌 樹*** 松井富士夫***
}

\section{Studies on Aqueous Corrosion of Iron and Steel}

by

\author{
Fumio Hine, Masaki Yasuda and Fujio MAtsui \\ (Department of Synthetic Chemistry, Nagoya Institute of Technology, Nagoya)
}

\begin{abstract}
Corrosion of iron and steel in neutral solutions of potassium chloride has been studied with rotating ring specimens. Since the oxide film deposited on the metal surface is much affected by small change of conditions, the corrosion rate vary significantly. The ratio of the maximum corrosion rate to the minimum rate, or to the average rate, is considered to be the "Safety Factor" under general corrosion conditions. The ratio was once recorded to be $1.5-2.5$ in aerated solutions of $\mathrm{KCl}$ at $50^{\circ} \mathrm{C}$, and was almost independent of the carbon and copper contents, probably due to the short-range experiment for only 100 hours.

The physico-chemical properties of oxyhydroxide that precipitated in the solution containing ferrous and/or ferric chloride were studied, i.e., the $\mathrm{pH}$ titration was carried out with a great variety, and the precipitates were examined by X-ray diffraction. Oxidation of both ferrous ions and oxyhdroxide precipitate with oxygen dissolved seems to be a major factor for formation of oxide film on ferro-metals.

(Received July 30, 1971)
\end{abstract}

\section{1 緒言}

鉄鋼の水溶液腐食についてはすで多くの論文, 総 説があり，筆者らもとくに酸素溶存系に関する実験結 果を報告した。それによれば， $\mathrm{pH}<4$ でははだか金属 表面での活性溶解であり, pH 4 10では金属表面に生 成した酸化物被膜によって腐食反応が著しく抑制され る。したがって中性溶液中での腐食はこの酸化物被膜 の生成条件やその物性によって支配されるであろう。 すでによく知られているょうに，鉄の酸化物の種類は 多いが, それらのさびと腐食との結びつきはまだそれ 活ど明りょうではない。ここでは

（1）実際に中性塩溶液中での腐食試験を行ない，腐 食速度とさびの観察を行なうとともに，

(2) 鉄塩水溶液を高濃度アルカリ溶液で $\mathrm{pH}$ 滴定し，

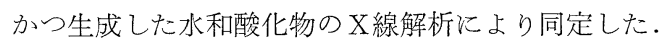
$\mathrm{pH}$ 滴定の環境, 条件と, 腐食試験時の環境, 条件と はかなりの隔たりは西るけれどもすすて増子らが指 摘したようそ，無機化学的考察がさびの挙動とその制 御の有力な手がかりになるであるう。

\section{$2 \cdot 1$ 腐食試験}

\section{2 実 験 方 法}

* 原禞受理 昭和 46 年 7 月30日

** 正会員 名古屋工業大学 名古屋市昭和区御器所町

*** 名古屋工業大学 名古屋市昭和区御器所町
さきに示したように, 酸素の溶存する水溶液中での 鉄鋼の腐食は酸素拡散律速型反応であるから，系の流 体力学的条件を規制する必要がある。また中性溶液中 での腐食試験結果は後述するように大幅に変動するの で，できるだけ数多くのデータを求めて統計的な考察 が必要である。そのため, 回転シャフトの先端の, 径 $15 \mathrm{~mm}$, 長さ $30 \mathrm{~mm}$ の Teflon sleeve に, 幅 $8 \mathrm{~mm}$ のリング状サンプル (面積約 $3.6 \mathrm{~cm}^{2}$ ) を1〜3 個取 付け， $250 \mathrm{cc}$ の腐食液を満たした $450 \mathrm{cc}$ ビーカーの 中央部没設置して定速モーター (1800 RPM) で回転 させた。同時に12槽運転したので, 1 条件につき最高 36点のデータを求めた。

主としてC抒よび $\mathrm{Cu}$ 含量の異なる9 種類の鉄鋼試 料 (Table I 参照) $650 \sim 700^{\circ} \mathrm{C}$ の $\mathrm{N}_{2}$ ふんん囲気で 20分間焼なましした後, 常法飞従って酸洗, 水洗し, 実験に供した。その腐食量は試験前後の重量減, お上 び溶出量の定量分析から求めた.

腐食液は $1 \mathrm{M} \mathrm{KCl}$ で，その $\mathrm{pH}$ は $\mathrm{HCl}$ または $\mathrm{KOH}$ で調整した。温度はすべて $50^{\circ} \mathrm{C}$.

空気の吹込及は,

(1)単なる開放 (以下, 開放系という), 拉よび

(2)強制吹込又（以下，通気系という）

の 2 方法を採用した。

このような試験法自体の可否を判定するために, 害 
Table I. Chemical analysis of specimens.

\begin{tabular}{|c|c|c|c|c|c|c|c|}
\hline Mark & $\mathrm{C}$ & $\mathrm{Mn}$ & $\mathrm{S}_{1}$ & $\mathrm{P}$ & S & $\mathrm{Cu}$ & $\mathrm{N}$ \\
\hline AS -3 & $\begin{array}{rr}0 & 002 \\
-0 & 003\end{array}$ & 0.39 & $<0.01$ & 0.010 & 0.014 & 0.0067 & 0.001 \\
\hline 01 & 0006 & 037 & 019 & 0003 & 0005 & $<001$ & \\
\hline 21 & 0008 & 030 & 015 & 0002 & 0007 & 018 & \\
\hline 41 & 0009 & 023 & 002 & 0002 & 0007 & 038 & \\
\hline 81 & 0006 & 042 & 030 & 0002 & 0005 & 079 & \\
\hline 05 & 022 & 033 & 0.13 & 0003 & 0006 & $<0 \quad 01$ & \\
\hline 25 & 021 & 055 & 026 & 0.010 & 0019 & 020 & \\
\hline 45 & 020 & 036 & 019 & 0015 & 0020 & 027 & \\
\hline $85 \mathrm{I}$ & 019 & 046 & 027 & 0009 & 0022 & 079 & \\
\hline
\end{tabular}

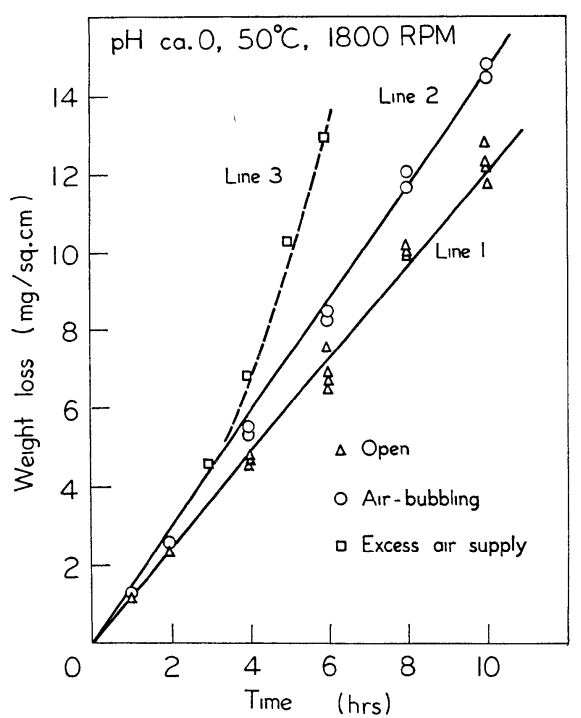

Fig. 1. Weight loss vs. time in acidified solution.

用上の純鉄 (AS-3) を $\mathrm{pH}$ ca. 0 の $1 \mathrm{M} \mathrm{KCl}$ 中で 試験した結果をFig. 1 亿示す。開放系 (Line 1) およ び通気系（Line 2) はともに原点をと抢る直線となり， からデーカの変動は充分小さい， Line 3 は空気を霧 状にして試料に強く吹付けた場合に得られた結果で, 試料表面には数多くの孔食が認められた。

\section{$2 \cdot 2 \mathrm{pH}$ 滴定}

$0.073 \mathrm{M} \mathrm{FeCl}_{2}$ 㧊よび $0.092 \mathrm{M} \mathrm{FeCl}_{3}$ の塩酸酸性 溶液（初期 $\mathrm{pH}$ ca. 3) を試料とし, $9 \mathrm{~N} \mathrm{NaOH}$ で滴定 し, $\mathrm{pH}$ 変化を記録した。酸・アルカリ中和反応の領 域での $\mathrm{pH}$ 変化の応答は速かであるけれども, 水和酸

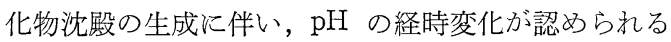
ようになる。このような場合には必要に応じて記録計 そより，それを追跡した。実験結果の説明の中に多少 このことが触れられている。

上記の鉄塩溶液忹一般の腐食環境に比べてかなり濃 厚であり，したがってこの実験に基づく知見がそのま ま腐食系に適用できるか否かの問題が残る。ごく希薄
な溶液の $\mathrm{pH}$ 滴定は充分な考察に耐えるだけの情報を 与光得ない。しかしながら、たと光ば $0.003 \mathrm{M} \mathrm{FeCl}_{2}$ と $2 \mathrm{~N} \mathrm{NaOH}$ の微量滴定から得たデー夕は $\mathrm{pH}$ 滴定 曲線永よび生成した沈殿物性が濃厚溶液の場合と類似 していることを示した。

$\mathrm{pH}$ 滴定漈し，腐食系との関連を考光るために必 要に応じて純鉄粉を試料液に加兄た。

所定の条件下で生成する沈殿をX線回折によって同 定した。また沈殿の色は生成条件淿よって黄から黒ま でのさまざまな色調をもっているのでカラー写真にと った. Fig. 4〜8 中の label 1〜15 はと机に該当する 位置，また Table III には色調を略記した。

\section{3 結 果と考察}

\section{$3 \cdot 1$ 腐食試験}

腐食試験結果の変動幅はFig. 2 亿示すように, 開放 系と通気系とを問わず著しく大きく，また表面のさび 層も肉眼でわかる程度に異なる。これはわれわれの制 御し得ていない要因がひそんでいることを意味する。 液の分析から求めた結果も同様の変動を示すが，その 幅はやや狭い，乙かしこれが腐食現象の1つの実情で あろう。したがってたと党ば装置材料の選択と使用に あたってこの幅を「安全率」と考光て考慮する必要が ある。

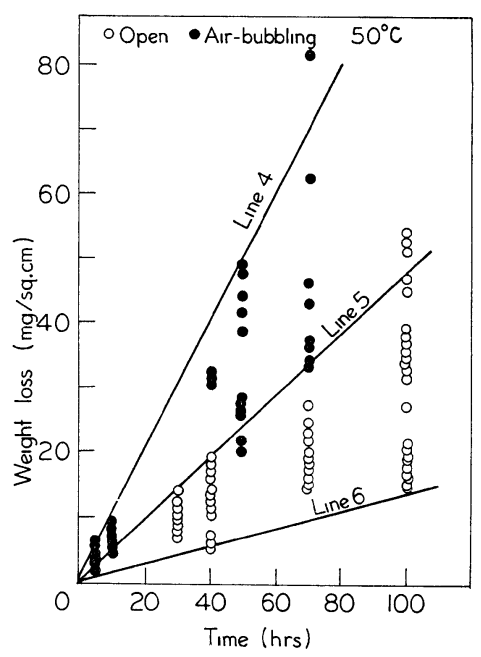

Fig. 2. Weight loss vs. time in neutral solution.

図に打いて，Line 4 和よび5はそれぞれ通気系物 よび開放系の上限を，また通気系の下限は偶然 Line 5 と重なり, 開放系の下限は Line 6 となる。これら の直線の傾きから腐食速度を計算し, Table II の

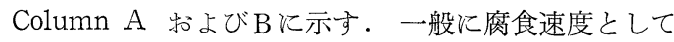
公表されているデータは，拈そらく数多くの実験值の 平均值である5。Column C はそそれを示す．安全率は $\mathrm{A} / \mathrm{B}$ または $\mathrm{A} / \mathrm{C}$ で表わされる. Table II によれば, 
Table II. Corrosion rate and safety factor evaluated from Fig. 2.

\begin{tabular}{|c|c|c|c|c|}
\hline \multicolumn{2}{|c|}{ Corrosion rate $(\mathrm{mg} / \mathrm{sc}$} & $\mathrm{cm} / \mathrm{hr}$ ) & \multicolumn{2}{|c|}{ Safety factor } \\
\hline $\max . \quad(\mathrm{A})$ & $\min \quad(B)$ & ave $\quad(\mathrm{C}\rangle$ & $f_{1}=\mathrm{A} / \mathrm{B}$ & $f_{2}=\mathrm{A} / \mathrm{C}$ \\
\hline \multicolumn{5}{|c|}{ From wt loss } \\
\hline 100 & 048 & 074 & 208 & 1.35 \\
\hline 048 & 013 & 031 & 369 & 155 \\
\hline \multicolumn{5}{|c|}{ From chem analysis } \\
\hline 080 & 056 & 068 & 143 & 118 \\
\hline 0.48 & 027 & 038 & 178 & 126 \\
\hline \multicolumn{3}{|r|}{ (average) } & 225 & 134 \\
\hline Above . & ated & Open & & \\
\hline
\end{tabular}

設計計算などに際して，均一腐食に対し，通常 1.5 ,

最高 2.5 の安全率を算入しなければならないといえる。

Fig. 2 亿示す実駼結果飞损いて, 試料組成との相関 性は認めら玌なかった。この実験で上述のようにC抒 よび $\mathrm{Cu}$ 含量の異なる多種類の試料を供試したのは, これらの成分が括そらくさびの生成に重要な役割を果 すであ万らとの予想からであったが，この期待は完全 にはずれた。従来からいわれている含銅鋼の耐食性注， この腐食試験よりもはるかに長い期間沉いて該当す るものと思う。このあたりに短期試験の意味と限界と がある。分析によれば，溶液中には $\mathrm{Cu}^{2+}$ の存在は認

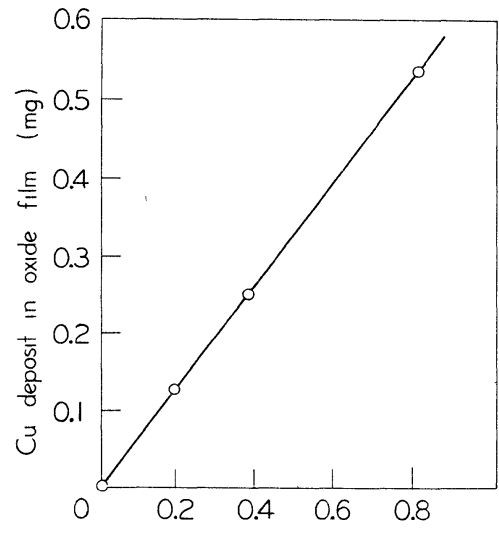

$\mathrm{Cu}$ content in specimen (\%)

Fig. 3. Copper content in the oxide film as a function of copper content in specimen.

められない. Fig. 3 はさび層中の $\mathrm{Cu}$ 含量の分析結果 で，試料金属の含銅量と簃密な直線性を有する。これ らの事実から，溶出した $\mathrm{Cu}$ は活とんど完全にさび層 に戻るか末なは残るものと考光られる。ささび層中の $\mathrm{Cu}$ の形は明らかではないが，含銅量の多い試料表面 には赤褔色の金属光沢の西るはん点が認められ，これ らの観察結果から，金属銅または低級酸化物として之 ぞまっているものと推定した。

\section{$3 \cdot 2 \mathrm{pH}$ 滴定結果}

Fig. 4 は $\mathrm{FeCl}_{2}$ 就よび $\mathrm{FeCl}_{3}$ の単味溶液の $\mathrm{pH}$ 滴

Table III. Experımental conditıons and results of observation of precipitates.

\begin{tabular}{|c|c|c|c|c|c|c|c|}
\hline \multirow{2}{*}{$\begin{array}{c}\text { Label } \\
\text { No }\end{array}$} & \multicolumn{5}{|c|}{ Conditions } & \multirow{2}{*}{ Color } & \multirow{2}{*}{ Composition predicted } \\
\hline & $\mathrm{Fe}$ (II) & $\mathrm{Fe}(\mathrm{III})$ & $\mathrm{Fe}$ & Alkalı & Aeration & & \\
\hline 1 & Yes & & & TI & No & Dark green & $\left(\gamma-\mathrm{Fe}_{2} \mathrm{O}_{3} \cdot \mathrm{H}_{2} \mathrm{O}\right) \mathrm{X}-1$ \\
\hline 2 & Yes & & & TI & No & Dark green to black after 1 day & $\left(\gamma-\mathrm{Fe}_{2} \mathrm{O}_{3} \cdot \mathrm{H}_{2} \mathrm{O}\right) \mathrm{Fe}_{3} \mathrm{O}_{4}$ \\
\hline 3 & Yes & & & $\mathrm{EQ}$ & No & Dark green & $\mathrm{Fe}(\mathrm{OH})_{2} \mathrm{X}-2$ \\
\hline 4 & Yes & & & EX & No & Dark brown after 1 day (Almost black) & $\mathrm{Fe}_{3} \mathrm{O}_{4} \mathrm{X}-3$ \\
\hline 5 & & Yes & & $\mathrm{TI}$ & No & Brown & Fine precipitate \\
\hline 6 & & Yes & & EX & No & Brown & $?$ \\
\hline 7 & & Yes & Yes & TI & No & Light brown after 10 minutes & $?$ \\
\hline 8 & & Yes & Yes & EX & No & Brownish black after 40 minutes & $\gamma-\mathrm{Fe}_{2} \mathrm{O}_{3} \mathrm{Fe}_{3} \mathrm{O}_{3}$ \\
\hline 9 & & Yes & Yes & $\mathrm{TI}$ & No & Dark green to black after $20 \mathrm{hrs}$ & $\mathrm{Fe}_{3} \mathrm{O}_{4} \alpha-\mathrm{Fe}_{2} \mathrm{O}_{3} \mathrm{X}-4$ \\
\hline 10 & Yes & Yes & & TI & No & Black & $\mathrm{Fe}_{3} \mathrm{O}_{4}$ \\
\hline 11 & Yes & & & TI & Yes & Orange yellow & $\begin{array}{l}\alpha-\mathrm{FeOOH} \mathrm{X-5}-5 \\
\gamma-\mathrm{Fe}_{2} \mathrm{O}_{3} \cdot \mathrm{H}_{2} \mathrm{O}\end{array}$ \\
\hline 12 & Yes & & & TI & Yes & Yellowish brown & $\alpha-\mathrm{FeOOH} \gamma-\mathrm{Fe}_{2} \mathrm{O}_{3} \cdot \mathrm{H}_{2} \mathrm{O}$ \\
\hline 13 & & Yes & Yes & TI & Yes & Reddish brown after $40 \mathrm{hrs}$ then yellowish black & $?$ \\
\hline 14 & & Yes & Yes & $\mathrm{EX}$ & Yes & Reddish brown after $20 \mathrm{hrs}$ then black & $?$ \\
\hline 15 & Yes & Yes & & TI & Yes & Dark reddish brown & $?$ \\
\hline
\end{tabular}




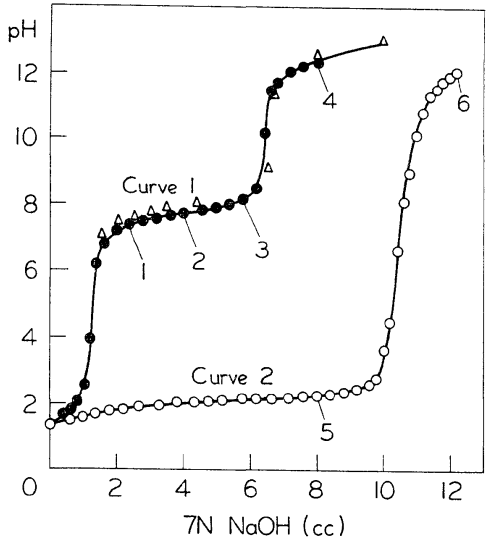

Curve $1 \quad 0 \quad 073 \mathrm{M} \mathrm{FeCl}_{2} \quad$ Curve $2 \quad 0 \quad 092 \mathrm{M} \mathrm{FeCl}_{3}$ F1g 4 Titration curves.

定曲線を示す. Curve 1 と抢いて, pH 7〜8 で生成 する沈殿は暗緑色で, $\mathrm{Fe}$ (II) の水和酸化物特有の色 をしている、X線回折の結果は，アルカリ不足 (lable 1), 当量点 (lable 3), 㧊上びアルカリ過剩 (lable 4) のいずれに拈いても未知組成 X-1, X-2，怙よび X-3 の peakが強く現われるが,これは異なった型のFe(II) 水和酸化物之考光られる。な打弱い $\gamma-\mathrm{Fe}_{2} \mathrm{O}_{3} \cdot \mathrm{H}_{2} \mathrm{O}$ の pattern が観測される汀れども，これは操作中の酸化 と上るもの之思わ机る. $\mathrm{Fe}(\mathrm{II})$ 水和酸化物沈殿を長 時間放置すれば次第に $\mathrm{Fe}_{3} \mathrm{O}_{4}$ を生成し，アルカリ不 足では黒色に，末たアルカリ過剩では褐色がかった黒 色になる (label 2 抢よび4)。この酸化反応は気液界 面からの空気中酸素の溶解によるものと思われる. Fe(III) の沈殿はいずれも amorphous で，かつ特有 の褐色である (label 5 出よび 6).

Fig. 5 は $\mathrm{FeCl}_{2}$ 溶液に鉄粉 $1 \mathrm{~g}$ を加光た場合の $\mathrm{pH}$ 滴定曲線である。図中の curve 2 は参考のために Fig.

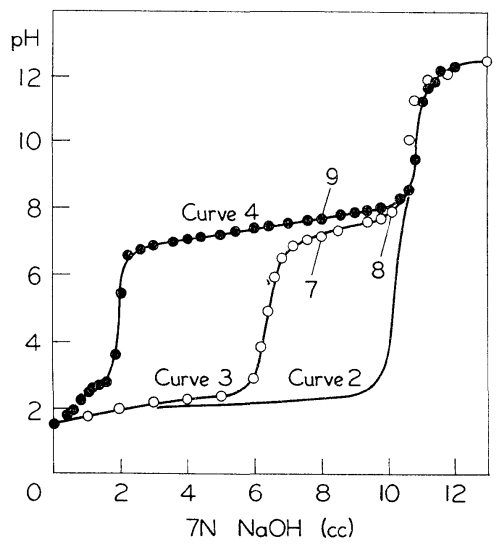

Curve $2 \quad 0092 \mathrm{M} \mathrm{FeCl}_{3}$

Curve 3 Above plus Fe powder after $5 \mathrm{~min}$ Curve 4 After $20 \mathrm{hrs}$

Fig 5. Titration curves.
4 の結果を転載した。鉄粉添加 10 分後の滴定曲線は curve 3 となり，生成した沈殿は赤褐色である (label 7)。この組成は詳かでないが，歀そらく $\gamma-\mathrm{FeOOH}$ 亦 たは $\gamma-\mathrm{Fe}_{2} \mathrm{O}_{3}$ と考光られる。時間がたつと沈殿は黒 色となり，強い $\gamma-\mathrm{Fe}_{2} \mathrm{O}_{3}$ と $\mathrm{Fe}_{3} \mathrm{O}_{4}$ の pattern が現 われる (label 8). 鉄粉添加後, さらに長時間経過す 孔ば, curve 4 の上 5 飞 Fe(II) 水和酸化物沈殿生成 を伴 $5 \mathrm{pH}$ 滴定曲線が得られ，沈殿の組成は $\mathrm{Fe}_{3} \mathrm{O}_{4}$, $\alpha-\mathrm{Fe}_{2} \mathrm{O}_{3}$ 少よび未知成分 $\mathrm{X}-4$ からなる。このように 鉄粉添加によって

$$
\mathrm{Fe}+\mathrm{Fe}^{3+}=\mathrm{Fe}^{2+}
$$

がかなりすみやかに進んだものと考えられる。

$\mathrm{pH}$ 滴定線は空気吟込及によって著しく変わる。 Fig. 6 は $\mathrm{FeCl}_{2}$ 溶液を通気下て滴定した結果を示す. 中和が注㜔完了して沈殷生成の始玉 いたると $\mathrm{pH}$ の経時变化が著しく，アルカリ添加によ って急昇した後，次第に下降して pH ca. 3 で落付く

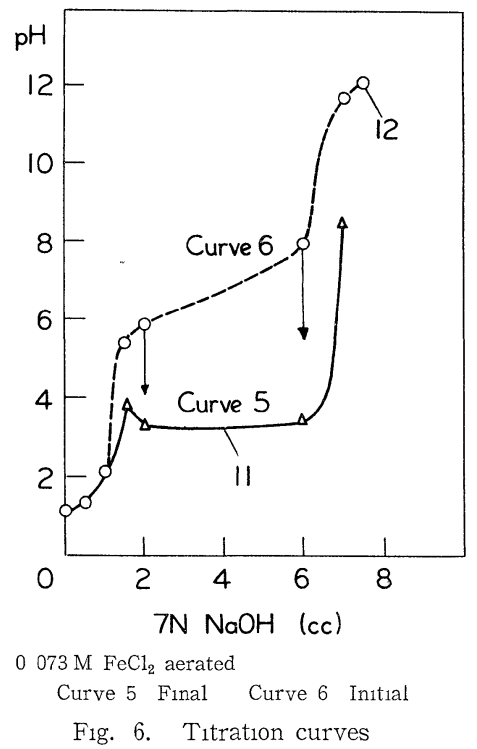

(図中の矢印). Curve 5 はこの最終 $\mathrm{pH}$ を連放たる ので, curve 6 は初期の值を連放たるのである. 重要 なことは, label 11 の示す $\mathrm{pH}$ は，Fig. 4 扮よび 5 に現われた plateau の值とは全く異なる。沈殿は黄 色 (orange yellow) であり, 強い $\alpha-\mathrm{FeOOH}$ ととも に未知の X-5 特よび $\gamma-\mathrm{Fe}_{2} \mathrm{O}_{3} \cdot \mathrm{H}_{2} \mathrm{O}$ の patternを示 す。アルカリ過剩の領域での色調は異なるが，X線回 折像は変わらない (label 12).

Fig. 7 は $\mathrm{FeCl}_{3}$ 溶液に鉄粉 $1 \mathrm{~g}$ を添加し，通気し ながら滴定した結果を示す。曲線の形はFig. 6 と添湆 同様で方り, 反応(1)飞よって生成した $\mathrm{Fe}^{2+}$ が溶存酸 素によって酸化されながら沈殿生成するものと思われ る.最初は赤褐色であり，時間が経つと次第に黒色飞 


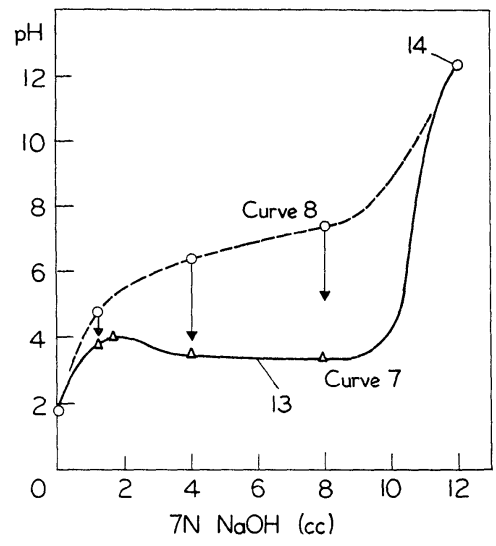

$0092 \mathrm{M} \mathrm{FeCl}_{3}$ plus $\mathrm{Fe}$ powder

Curve 7 Final (after 15min)

Curve 8 Initial

F1g. 7 Titration curves.

変わる(1abel 13 および 14)。組成は確かでないが， 抢そらく最初は $\mathrm{Fe}$ (II) と $\mathrm{Fe}$ (III) の水和酸化物の混 合物であり, 次第に $\gamma-\mathrm{FeOOH}$ または $\gamma-\mathrm{Fe}_{2} \mathrm{O}_{3}$ 飞変 化する。この系が中性溶液中の腐食反応の過程と最も 近いと考光られる。ここでも落ち付く $\mathrm{pH}$ が注湆 3 で ある. 反応機構の詳細はこの上うな簡単な実験では解 らない恬れども，まず $\mathrm{Fe}^{2+}$ が $\mathrm{pH} 7$ 8 に扔いて $\mathrm{Fe}$ (II) 水和酸化物として沈殿した後, 溶存酸素によ って $\mathrm{Fe}_{3} \mathrm{O}_{4}$, 続いて $\mathrm{Fe}_{2} \mathrm{O}_{3}$ 酒酸されていくものと 考えられる。ここで示した $\mathrm{pH}$ 滴定と腐食反応の進む 過程とは操作時間が全く異なるために, 酸化反応の手 順が違い，このあたりがさび生成の決め手となるよう 飞思われる。たと党ば $\mathrm{Fe}$ (II) 水和酸化物があらかじ め生成した後, $\mathrm{Fe}$ (III) 酸化物に酸化されていくの之, $\mathrm{Fe}^{2+}$ の一部が $\mathrm{Fe}^{3+}$ にあらかじめ酸化されて, $\mathrm{Fe}$ (II) 之 $\mathrm{Fe}$ (III) の水和酸化物が共沈するのと性非常に違う。

Fig. 8 は $\mathrm{FeCl}_{2}$ および $\mathrm{FeCl}_{3}$ 混合溶液の通気下で の滴定曲線を示す. Curve 9 は参考のために通気せず に速かに得た曲線で, Fig. 4 の結果と比較して, 単な る混合溶液の滴定曲線として充分理解でき，かつ量論 的飞も正しい。しかし得られた沈殿 (label 10) は, 黒 色であり，Table III， label 2 拉よび4のように， $\mathrm{Fe}$ (II) 沈殿生成後，ゆるやかに酸化脱水されていく 場合々同様儿， $\mathrm{Fe}^{2+}$ および $\mathrm{Fe}^{3+}$ の混合溶液からも 適当な混合条件（濃度比など）の下では $\mathrm{Fe}_{3} \mathrm{O}_{4}$ の沈殿 することがわかる。

Curve 10 は通気しながら求めた曲線であり, curve 11はさらに数分間通気後求めた曲線である.この両者 の傾向から，Fig. 6 または 7 で述べた $\mathrm{pH}$ 変動と同様 に見受けられるが， label 15 の沈殿は赤褐色であり， かつ技そらく $\gamma-\mathrm{FeOOH}$ 本たは $\gamma-\mathrm{Fe}_{2} \mathrm{O}_{3}$ であり, $\mathrm{Fe}_{3} \mathrm{O}_{4}$

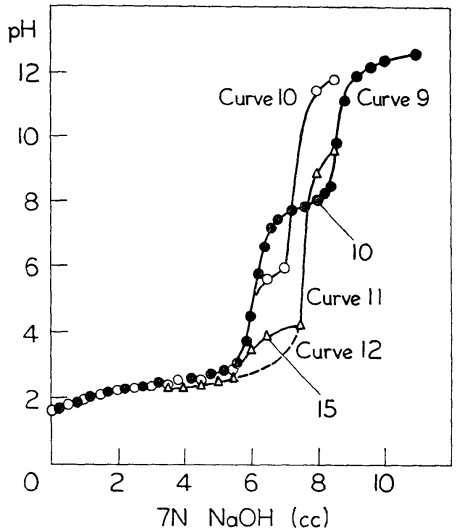

$0073 \mathrm{M} \mathrm{FeCl}_{2}+0092 \mathrm{M} \mathrm{FeCl}_{3}$

Curve 9 Immediately

Curve 10 Aerated solution

Curve 11 After few minutes

Fig. 8. Titration curves.

は全く見い出せない，ただし label 15 の存在する $\mathrm{pH}$ は湮淩3であり，Fig. 6 李たは 7 の plateau とよく 一致する。したがって curve 10 から11へは径時的 飞変化すると述べたが，さらに長時間の経過によって curve 12 にいたるとは考えられない。

\section{4 結言}

中性塩溶液中での鉄鋼の腐食速度を開放系および通 気系で測定したところ，データの変動幅は1.5〜2.5倍 の広い範囲沈たった。しかしこれが腐食の実体であ ろうと受止めた。これは鉄表面での水和酸化物生成の 機構のわずかな違いによるるのと想像される。そこで, 種々の条件下で, $\mathrm{pH}$ 滴定, X線回折, および色調の 観察などから水和酸化物生成関する無機化学的考察 を試みた。以上の $\mathrm{pH}$ 滴定結果と，中性溶液中での腐 食生成物とはなだ何の適切な結び付きもないけれども このような知見がいずれ一つの有力な手がかりになる ものと思了。

この研究は株式会社山崎精機研究所の援助によって 行なった。また鉄鋼試料は住友金属工業株式会社中央 技術研究所より提供された。ここに記して謝意を表す る.

（昭和46年 8 月 25 日 第18回腐食防食討論会て講演）

\section{参 考 文 献}

1）日根文男, 保田昌樹, 馬場清治, 山川宏二, 中川 保, 電化, 38, 893 (1970).

2) Strauss, M. B., and M. C. Bloom, J. Electrochem. Soc, 107, 73 (1960).

3）高田利夫, 電化，37，328（1969）.

4）增子 昇, 久松敬弘, 第 13 回腐食防食討論会, A311 (1966，松山). 